\title{
In vivo antiplasmodial and toxicological effect of Maytenus senegalensis traditionally used in the treatment of malaria in Tanzania
}

\author{
Hamisi M Malebo ${ }^{1 *}$, Victor Wiketye ${ }^{2}$, Shaaban J Katani ${ }^{1}$, Nteghenjwa A Kitufe ${ }^{1}$, Vitus A Nyigo ${ }^{1}$, Calister P Imeda', \\ John W Ogondiek2, Richard Sunguruma', Paulo P Mhame, Julius J Massaga ${ }^{4}$, Bertha Mammuya ${ }^{5}$, \\ Kesheni P Senkoro ${ }^{4}$, Susan F Rumisha ${ }^{4}$, Mwelecele N Malecela ${ }^{4}$ and Andrew Y Kitua ${ }^{4}$
}

\begin{abstract}
Background: In Tanzania and elsewhere, medicinal plants, including Maytenus senegalensis, are still widely used in the treatment of malaria and other ailments. The aim of the present study was to investigate the in vivo antiplasmodial and toxic effects in mice.

Methods: Oral antiplasmodial and acute toxicity of the ethanolic root extract of $M$. senegalensis was evaluated in mice. The Peters 4-day in vivo antiplasmodial effect against early rodent malaria infection in chloroquine-sensitive Plasmodium berghei NK 65 strain in mice.

Results: The M. senegalensis extract was found non-toxic and the oral median lethal dose in mice was determined to be greater than $1,600 \mathrm{mg} / \mathrm{kg}$ body weight. The findings revealed a significant $(P=0.001)$ daily increase in the level of parasitaemia in the parasitized untreated groups and a significant $(P<0.001)$ dose dependent decrease in parasitaemia in the parasitized groups treated with varying doses ranging from 25 to $100 \mathrm{mg} / \mathrm{kg}$ body weight of $\mathrm{M}$. senegalensis extract and the standard drug sulphadoxine/pyrimethamine at $25 / 1.25 \mathrm{mg} / \mathrm{kg}$ body weight. Overall, the dose dependent parasitaemia suppression effects were in the order of: $25 / 1.25 \mathrm{mg} / \mathrm{kg}$ body weight of sulphadoxine/ pyrimethamine $>100 \mathrm{mg} / \mathrm{kg}>75 \mathrm{mg} / \mathrm{kg}>50 \mathrm{mg} / \mathrm{kg}>25 \mathrm{mg} / \mathrm{kg}$ body weight of $M$. senegalensis extract.

Conclusion: The implications of these findings is that $M$. senegalensis ethanolic root bark extract possess potent antiplasmodial effect and may, therefore, serve as potential sources of safe, effective and affordable anti-malarial drugs. The displayed high in vivo antiplasmodial activity and lack of toxic effect render $M$. senegalensis a candidate for the bioassay-guided isolation of compounds which could develop into new lead structures and candidates for drug development programmes against human malaria.
\end{abstract}

Keywords: Maytenus senegalensis, Malaria, Plasmodium berghei, Antiplasmodial, Acute toxicity

\section{Background}

Maytenus senegalensis, which belong to the Celastraceae family, is an abundant perennial tree that has a wider distribution in Africa, Arabia, Afghanistan and India [1]. The decoction of the stem bark and root is used traditionally in the folk medicine in Africa for the treatment of a number of diseases and health conditions, including

\footnotetext{
* Correspondence: Malebo@hotmail.com

'Department of Traditional Medicine Research, National Institute for Medical Research, 3 Barack Obama Drive, P.O. Box 9653, 11101 Dar es Salaam, Tanzania

Full list of author information is available at the end of the article
}

malaria, fever, chest pains, rheumatism, dysmenorrhoea, diarrhoea, dyspepsia eye infection, wounds and snakebites $[2,3]$.

In Kagera region, in Tanzania, the root bark is used in traditional medicine by traditional healers and the community to treat malaria, fever, pain and chronic illnesses $[2,4]$. The same traditional uses of $M$. senegalensis are also reported from other African countries namely; Benin, Côte d'Ivoire, Kenya, Senegal, Sudan, Zambia, and Zimbabwe [5-11]. Most of the population in rural communities in Tanzania and in other African countries relies on herbal medicines for their health 
Table 1 Percent Parasitaemia per dose in $\mathrm{mg} / \mathrm{kg}$ body weight of mouse

\begin{tabular}{|c|c|c|c|c|c|c|c|}
\hline \multirow[t]{2}{*}{ Doses } & \multicolumn{5}{|c|}{ Percent Parasitaemia per mouse (\%) } & \multirow[t]{2}{*}{ Mean (\%) } & \multirow{2}{*}{$\begin{array}{l}\text { Pvalue of Tests } \\
\text { vs Neg. control }\end{array}$} \\
\hline & 1 & 2 & 3 & 4 & 5 & & \\
\hline 25 & 6.25 & 6.75 & 6.50 & 6.80 & 6.20 & 6.50 & $P<0.001$ \\
\hline 50 & 3.66 & 3.69 & 3.43 & 3.80 & 3.40 & 3.59 & $P<0.001$ \\
\hline 75 & 2.06 & 2.10 & 1.54 & 2.00 & 1.80 & 1.90 & $P<0.001$ \\
\hline 100 & 0.90 & 0.96 & 1.16 & 1.08 & 0.90 & 1.10 & $P<0.001$ \\
\hline Neg. control & 56.58 & 56.45 & 56.57 & 56.56 & 56.51 & 56.53 & \\
\hline SP $(25 / 1.25)$ & 0.49 & 0.80 & 0.76 & 0.72 & 0.65 & 0.68 & \\
\hline
\end{tabular}

care needs [12]. This stems from the cultural significance of indigenous people as well as the herbal medicines are generally more accessible, affordable and the perceived efficacy and safety of the remedy [13]. Despite the efforts of government of the United Republic of Tanzania to make modern health service accessible, available and acceptable to all, most of people in rural areas reside distances away from the facilities and that, the road infrastructure linking some of the communities to the health facilities are in some seasons of the year are inaccessible, especially during rainy seasons [14-16].

On this background coupled with other factors make it difficult for the majority of rural dwellers to access quality health care and unequivocally make traditional medicine an obvious choice for them. In Kagera region in Tanzania, dependency on traditional medicine as the first option for rural dwellers in the treatment of malaria has been inevitable. Despite the popular use of M. senegalensis for malaria and other ailments, few pharmacological studies have been described in literature and there is no extensive research on the toxicity of extracts of the root bark and their pharmacological effect on malaria. Thus, the interest in this plant was justified by its potential medicinal value against malaria. Therefore, the aim of this study was to investigate the in vivo efficacy and safety of the root bark extract of M. senegalensis.

\section{Methods \\ Chemicals}

Analar grade ethanol and dimethyl sulphoxide (DMSO) were purchased from VWR (UK).

\section{Plant collection and sample preparation}

Root bark materials of $M$. senegalensis were collected by the help of the traditional healers and community members at Kyamlaire village in Kagera region, Tanzania. Identification of the plant species was done at the Herbarium of the Department of Botany, University of Dar es Salaam where a voucher specimen has been deposited (Suleman collection No. 4998). The root bark was air dried, grinded and phytochemical processing to get crude ethanolic extract was done. Two kilograms of air-dried and ground root bark of $M$. senegalensis was soaked in $6 \mathrm{~L}$ ethanol for 48 hours at room temperature (about $30^{\circ} \mathrm{C}$ ). The crude extract was obtained by filtration, followed by evaporation of the solvent in vacuo at $30^{\circ} \mathrm{C}$ so as to avoid decomposition of thermally labile compounds. The afforded extract weighing $244 \mathrm{~g}\left(12.2 \%\right.$ yield) was kept at $4{ }^{\circ} \mathrm{C}$ in the refrigerator till when needed for assay.

\section{Animals}

Swiss albino mice weighing 18-22 g and aged 6-8 weeks raised at the Animal House of the Government Chemist Laboratory Agency (GCLA) were used in the study. The mice

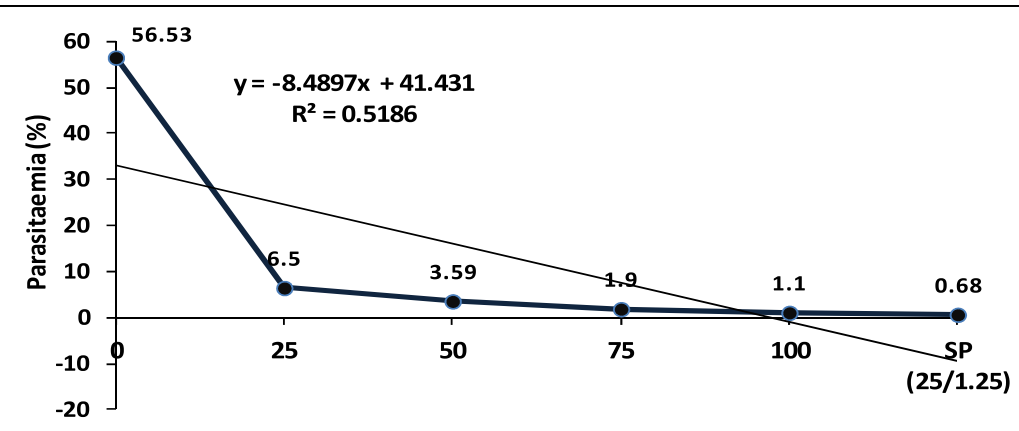

Dosages of $M$. senegalensis

Figure 1 Suppression of Plasmodium berghei parasitaemia exhibited by different dosages of M. senegalensis in comparison to controls in experimentally infected mice. 


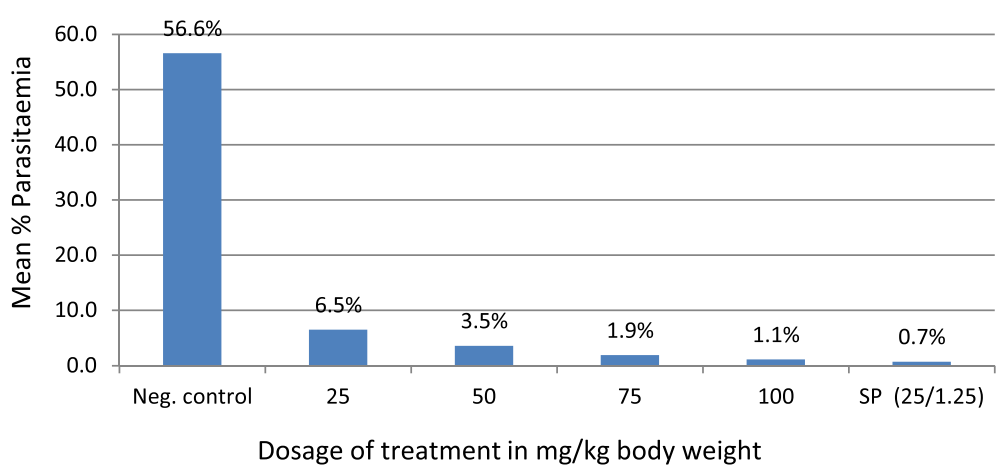

Figure 2 Percent parasitaemia observed with different dosages of $M$. senegalensis in comparison to controls in experimentally infected mice.

were maintained on standard feed and water (ad libitum). Approval for the study was obtained from the Ethical Committee, National Institute for Medical Research (NIMR) in Tanzania.

\section{Parasite}

Blood-stage samples of Plasmodium berghei ANKA 65 strain were stored in liquid nitrogen in solution for cryopreservation of the parasite till needed for the assay.

\section{Infection of mice}

Albino mice between 6 to 8 weeks of age and weighing between 18 to 22 grams were randomized into six groups of five each and with the exception of the healthy control group, all mice were inoculated intravenously in the tail vein on day 1 with $1 \times 10^{7} P$. berghei ANKA 65 parasitized erythrocytes obtained by suitable dilution with $0.9 \% \mathrm{NaCl}$ of infected red blood cells from a sacrificed mouse with $20 \%$ parasitaemia.

\section{Drug administration}

This was the four-day suppressive test $[17,18]$. The $M$. senegalensis root bark ethanolic extract was dissolved in DMSO and then diluted with distilled water to $1 \%$ DMSO to make concentrations of 25, 50, 75 and $100 \mathrm{mg} / \mathrm{kg}$ body weight in each $0.4 \mathrm{ml}$ of the extract once a day (at 24-hour interval) for four days post-infection (p.i.). Likewise sulphadoxine/pyrimethamine (SP) was dissolved in $1 \%$ DMSO at a concentration of $25 / 1.25 \mathrm{mg} / \mathrm{kg}$ in $0.4 \mathrm{ml}$. The first four groups each were treated with crude M. senegalensis root bark ethanolic extract once daily starting on day 1 with $0.4 \mathrm{ml}$ of each one of the test dosage through the oral route. The fifth group was treated with standard drug (SP) and served as the positive control. The sixth group received the vehicle and served as untreated controls. Treatments were continued for days 2,3 , and 4 . The course of infection was followed up on day 7 by a Giemsastained blood smear determination of parasitaemia.

The percentage of parasitaemia for each group was calculated using the formula:

$$
=\frac{(\text { mean parasitaemia treated }) \times 100}{\text { Mean parasitaemia control }}
$$

The percent inhibition of parasitaemia for each group was calculated using the formula

$$
=100-\frac{(\text { mean parasitaemia treated } \times 100)}{\text { Mean parasitaemia control }}
$$

\section{In vivo acute toxicity assessment}

Crude M. senegalensis root bark ethanolic extract was assessed for its toxicity in vivo in albino mice according to WHO guidelines [19]. Crude M. senegalensis root bark ethanolic extract was dissolved in DMSO and then diluted with distilled water to $1 \%$ DMSO to make concentrations of 200,300, 400, 800 and $1600 \mathrm{mg} / \mathrm{kg}$ body weight. Five groups of ten albino mice each were used during the study

Table 2 The calculated percentage of suppression (inhibition) of Plasmodium berghei per dose

\begin{tabular}{llll}
\hline Dose in $\mathbf{~ m g} / \mathbf{k g}$ body weight & Calculation of \% inhibition of parasitaemia & Percent inhibition & $\boldsymbol{P}$ value of Pos. control vs Tests \\
\hline 25 & $100-[6.5 / 56.53 \times 100]$ & $\mathbf{8 8 . 5 0}$ & $\mathrm{P}<0.05$ \\
50 & $100-[3.59 / 56.53 \times 100]$ & $\mathbf{9 3 . 6 5}$ & $\mathrm{P}<0.05$ \\
75 & $100-[1.9 / 56.53 \times 100]$ & $\mathbf{9 6 . 6 4}$ & $\mathrm{P}>0.05^{*}$ \\
100 & $100-[1.1 / 56.53 \times 100]$ & $\mathbf{9 8 . 0 5 4}>0.05^{*}$ \\
Negative control & $100-[56.53 / 56.53 \times 100]$ & $\mathbf{0}$ & \\
Positive control (SP) $(25 / 1.25$ & $100-[0.52 / 56.53 \times 100]$ & $\mathbf{9 9 . 0 8}$ & \\
\hline
\end{tabular}

*SP (standard drug) has no marked superiority to M. senegalensis extract at a dose of 75-100 mg/kg. 


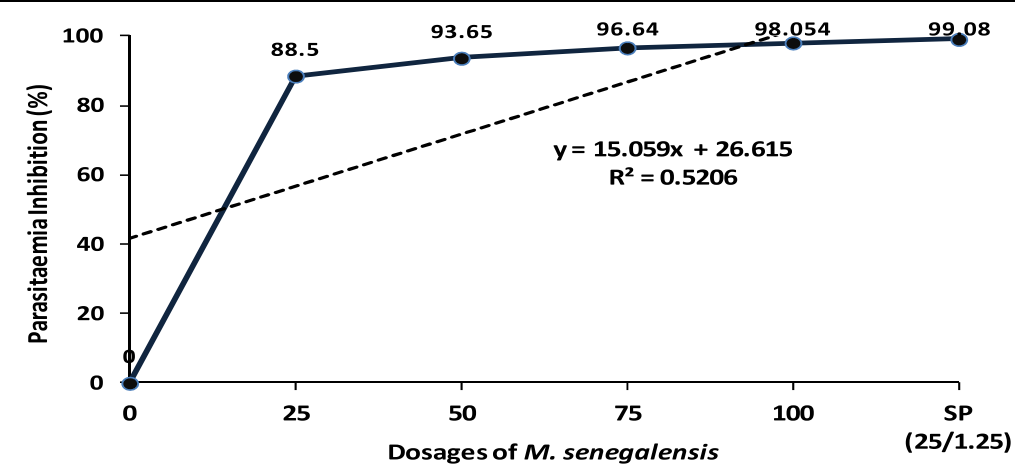

Figure 3 Suppression of Plasmodium berghei parasitaemia exhibited by different dosages of $M$. senegalensis in comparison to controls in experimentally infected mice.

including five males and five females. Male and female young adult mice were randomized and doses of $M$. senegalensis were administered by oral gavage. After drug administration, food was withheld for $2 \mathrm{~h}$. Mice were observed individually for 4 hours after drug administration and then at the $24 \mathrm{~h}$ and $48 \mathrm{~h}$. All mice were observed to identify any symptoms manifesting ill-health or behavioural changes. Visual observation parameters included alertness, grooming, tremors, convulsions, urination, salivation and writhing. The median oral lethal dose calculated as the geometric mean of doses that caused between 0 and 100\% mortality (if any). The definition of the acute toxicity used was: $0 \leq 50 \mathrm{mg} / \mathrm{kg}$ body weight - highly toxic; $50 \leq 300 \mathrm{mg} / \mathrm{kg}$ body weight toxic; $300 \leq 1,000 \mathrm{mg} / \mathrm{kg}$ body weight - moderately toxic; $1,000 \leq 2,000 \mathrm{mg} / \mathrm{kg}$ body weight - mildly toxic; and $2,000 \leq 5,000 \mathrm{mg} / \mathrm{kg}$ body weight - non-toxic.

\section{Statistical analysis}

Data was analysed by statistical software SPSS version 11.5 (SPSS Inc, Chicago, Illinois, USA). Numerical data presented as mean \pm standard deviation, the significance of mean difference between two independent groups was determined by using Student's $t$-test, and one-way analysis of variance (ANOVA). A $P$ value $<0.05$ was considered significant. Proportional data was presented as percentages. Significance testing of differences between proportions was done by using Fisher's exact test, a $P$ value $<0.05$ was considered significant.

Table 3 Probit analysis of in vivo antiplasmodial activity of $M$. senegalensis ethanol extract in experimental mice

\begin{tabular}{lll}
\hline Probit & $\begin{array}{l}\text { Antiplasmodial activity } \\
\text { in } \mathbf{~ m g / k g ~ B D W ~}\end{array}$ & $\begin{array}{l}\text { Range at confidence interval } \\
\mathbf{9 5 \%} \text { limits }(\mathbf{m g} / \mathbf{k g ~ B D W})\end{array}$ \\
\hline $\mathrm{ED}_{50}$ & 3.3 & 1.8 to 4.9 \\
$\mathrm{ED}_{75}$ & 10.2 & 7.2 to 13.5 \\
$\mathrm{ED}_{90}$ & 28.4 & 21.6 to 39.3 \\
$\mathrm{ED}_{99}$ & 166.5 & 102.4 to 349.8 \\
\hline
\end{tabular}

Slope $=1.361+-0.162 ;$ Natural Response. $=0.000+-0.000 ;$ Heterogeneity $=0.04$.

\section{Results}

In vivo anti-plasmodial activity

The results of the in vivo antiplasmodial effect of $M$. senegalensis ethanol extract showed a dose-dependent significant decrease in malaria parasite count in mice infected with $P$. berghei $(P=0.001)$. Table 1 and Figures 1 and 2 show summary of the percentage parasitaemia in mice on day 7 post-infection (p.i.).

Based on day 7 p.i. smears, the $M$. senegalensis ethanol extract dosages ranging from $25-100 \mathrm{mg} / \mathrm{kg}$ body weight, exhibited significant suppression of parasitaemia ranging from $88.5 \%$ to $98.1 \%(p=0.001)$ as shown in Table 2 and Figure 3. The highest reduction of parasitaemia was observed at a dose of $100 \mathrm{mg} / \mathrm{kg}$ body weight of mice treated with $M$. senegalensis ethanol extract as compared to the negative control group. At $100 \mathrm{mg} / \mathrm{kg}$ body weight, the $M$. senegalensis ethanol extract exhibited $98.1 \%$ suppression of parasitaemia comparable to $99.1 \%$ that of SP, the positive control. The in vivo antiplasmodial activity of $M$. senegalensis was expressed by the dose inhibiting 50\%, 75\%, $90 \%$ and $99 \%$ of parasite growth $\left(\mathrm{ED}_{50}, \mathrm{ED}_{75}, \mathrm{ED}_{90}, \mathrm{ED}_{99}\right)$. The effective dose that cured $50 \%$ of test mice $\left(E_{50}\right)$ was calculated as $3.3 \mathrm{mg} / \mathrm{kg}$ body weight which indicates that the $M$. senegalensis ethanol extract has high in vivo antiplasmodial activity in mice infected by $P$. berghei (Table 3 ). The extract also revealed other promising effective doses

Table 4 In vivo acute toxicity of $M$. senegalensis ethanol extract in experimental mice

\begin{tabular}{llll}
\hline Dose in $\mathbf{~ m g / k g}$ body weight & \multicolumn{3}{l}{$\begin{array}{l}\text { Acute toxicity } \\
\text { (survival at } \mathbf{2 4} \text { and } \mathbf{4 8} \text { hours) }\end{array}$} \\
\cline { 2 - 4 } & No. of mice & $\mathbf{2 4}$ hours & $\mathbf{4 8}$ hours \\
\hline 200 & 10 & 10 & 10 \\
300 & 10 & 10 & 10 \\
400 & 10 & 10 & 10 \\
800 & 10 & 10 & 10 \\
1600 & 10 & 10 & 10 \\
\hline
\end{tabular}


$\left(\mathrm{ED}_{75}, \mathrm{ED}_{90}\right.$ and $\left.\mathrm{ED}_{99}\right)$ at calculated dosages of 10.2, 28.4 and $166.5 \mathrm{mg} / \mathrm{kg}$ body weight, respectively.

\section{Acute toxicity}

Results of the acute toxicity evaluation of $M$. senegalensis ethanol extract are provided in Table 4. At all the tested dosages no any mouse died at 24 and 48 hours post drug administration. The highest tested dose was $1600 \mathrm{mg} / \mathrm{kg}$ of body weight. The animals were not exposed to doses higher than $1,600 \mathrm{mg} / \mathrm{kg}$ of body weight as with increasing concentration, the extract precipitated and the solution became too sticky to handle. Observations of physical conditions, toxic symptoms showed that no any sign of toxicity was seen in experimental mice at the tested dosages. The therapeutic index (TI) calculated as ratio of the $\mathrm{LD}_{50}$ and $\mathrm{ED}_{50}$ was estimated to be higher than 113.5, indicating that M. senegalensis ethanol extract is not toxic.

Table 4 shows the toxicity manifestation parameters observed before and after the administration of $M$. senegalensis ethanol extract. The statistical analysis of the dosage administered to mice and the observed effects were found significant at $5 \%$. No any toxic effect manifestation was observed even at the highest dosage of $1600 \mathrm{mg} / \mathrm{kg}$ body weight of the test mouse (Table 5). This clearly confirms that, the $M$. senegalensis ethanol extract do not produce oral toxicity at the tested dosages.

The lethal dose of $M$. senegalensis ethanol extract is higher than $1,600 \mathrm{mg} / \mathrm{kg}$ body weight and hence, in a single dose administration, the plant extract caused no any mortality.

\section{Discussion}

The ethanolic root bark extract of $M$. senegalensis showed high antiplasmodial activity against $P$. berghei infection in mice as evidenced by the percentage of inhibition of parasite development. The M. senegalensis extract exhibited higher suppression of malaria parasites comparable to that of the standard antimalarial drug, SP. Maytenus senegalensis extract exhibited a dose dependent activity, as the dose increased also antiplasmodial activity increased significantly. In addition, the observed chemosuppressive activity suggests that the root bark extract of this plant can suppress parasite growth to lower levels of parasitaemia in a long-term administration as it is practiced in traditional medicine. However, findings showing lower antiplasmodial effect with parasitaemia suppression of $7 \%$ and $23 \%$ of $M$. senegalensis leaves and root bark, respectively, have been reported [10]. It was furthermore revealed that, the parasitaemia suppression of M. senegalensis leaves and root bark extracts were potentiated by chloroquine to $55.4 \%$ and $56.2 \%$, respectively [10]. High antiplasmodial effects on parasitaemia in this study are similar to the ones reported by Gessler et al. [2], whereby M. senegalensis extract at the dosage of $500 \mathrm{mg} / \mathrm{kg}$ body weight/day in four days produced a significant reduction of parasitaemia of $90 \%$. Previous in vitro screening revealed M. senegalensis extract exhibits strong activity against the multi-drug resistant Plasmodium falciparum strain $\mathrm{K} 1$ with $\mathrm{IC}_{50}$ values of ranging from 1.0 to $3.9 \mu \mathrm{g} / \mathrm{ml}$ [2,20,21]. The extracts of M. senegalensis also exhibit potent antiinflammatory, analgesic and antipyretic properties in mice [22,23]. These findings support the ethnomedical use of $M$. senegalensis in the treatment of malarial and associated symptoms.

In this study, the extract of $M$. senegalensis did not show any toxic effect because doses up to $1600 \mathrm{mg} / \mathrm{kg}$ caused no any death or alter the behaviour of the tested normal mice. It can be extrapolated that, the median lethal dose is thus greater than $1600 \mathrm{mg} / \mathrm{kg}$ making $M$. senegalensis safety to be between slightly toxic to nontoxic. However, Da Silva et al., in the preliminary toxicity study, noted signs of toxicity of $M$. senegalensis in mice and rats at $1,200 \mathrm{mg} / \mathrm{kg}$ body weight [24]. However, a similar finding has not yet been found by other researchers worked on $M$. senegalensis extracts. Recent investigation in Tanzania has further revealed that, $M$. senegalensis extract is practically non-toxic as it is well

Table 5 Toxicity effect manifestation of $M$. senegalensis ethanol extract in experimental mice

\begin{tabular}{|c|c|c|c|c|c|c|c|c|c|c|}
\hline \multirow[t]{3}{*}{ Response } & \multicolumn{10}{|c|}{ Dosage of extract administered to test mice (mg/kg body weight) } \\
\hline & \multicolumn{2}{|l|}{200} & \multicolumn{2}{|l|}{300} & \multicolumn{2}{|l|}{400} & \multicolumn{2}{|l|}{800} & \multicolumn{2}{|l|}{1600} \\
\hline & Before & After & Before & After & Before & After & Before & After & Before & After \\
\hline 1. Alertness & $\mathrm{N}$ & $\mathrm{N}$ & $\mathrm{N}$ & N & $\mathrm{N}$ & $\mathrm{N}$ & $\mathrm{N}$ & $\mathrm{N}$ & $\mathrm{N}$ & $\mathrm{N}$ \\
\hline 2. Grooming & A & A & A & A & A & A & A & A & A & A \\
\hline 3. Tremors & A & A & A & A & A & A & A & A & A & A \\
\hline 4. Convulsion & A & A & A & A & A & A & A & A & A & A \\
\hline 5. Urination & $N$ & $\mathrm{~N}$ & $\mathrm{~N}$ & $N$ & $\mathrm{~N}$ & $\mathrm{~N}$ & $N$ & N & N & $N$ \\
\hline 6. Salivation & N & $\mathrm{N}$ & $\mathrm{N}$ & $N$ & $\mathrm{~N}$ & $\mathrm{~N}$ & $N$ & N & N & N \\
\hline 7. Writhing & A & $A$ & A & A & A & A & A & A & $A$ & A \\
\hline
\end{tabular}

Key: $\mathrm{N}=$ normal; $\mathrm{A}=$ absent. 
tolerated and without any sign of toxicity in experimental mice. In the acute toxicity study, it was indicated that, the extract at a dose of $5,000 \mathrm{mg} / \mathrm{kg}$ body weight caused neither visible signs of toxicity nor mortality in mice, suggesting its safety [25]. In the classification of toxicity, the extract with an $\mathrm{LD}_{50}>5,000 \mathrm{mg} / \mathrm{kg}$ body weight per os (p.o.) is considered to be non-toxic. Investigation in Mali revealed that, the aqueous extract of $M$. senegalensis administrated orally in mice caused no any toxicity to mice [22]. Previous findings also suggest that $M$. senegalensis is practically non-cytotoxic as it exhibited $\mathrm{IC}_{50}$ values of $87.82 \pm 3.02$ and $>90.00$ against mammalian cell lines viz; Vero cell lines and Rat skeletal myoblast (L-6) cells, respectively $[20,21]$. The oral nontoxic nature of $M$. senegalensis and the use of this plant against malaria and other ailments go hand in hand with scientific evidence provided by this study.

\section{Conclusion}

The oral administration of graded $M$. senegalensis ethanol extract doses $(25-100 \mathrm{mg} / \mathrm{kg}$ body weight) to mice for 4 days significantly suppressed malaria parasites development in vivo against Plasmodium berghei NK 65 strain in experimental mice. Higher doses of M. senegalensis ethanol extract (200-1600 mg/ $\mathrm{kg}$ body weight) could not result in death and was not associated with adverse effects. According to these results, the M. senegalensis ethanol extract could be categorized as a nontoxic crude drug that acts harmlessly under the normal traditional usage. The observed large safety window of M. senegalensis extract is responsible for its widespread use in Tanzania and other countries without acute toxic symptoms and complications. Hence, $M$. senegalensis may be exploited as herbal pharmaceuticals for malaria, fever and pains. The implications of these findings is that $M$. senegalensis ethanolic root bark extract possess potent antiplasmodial effect and may therefore serve as potential sources of safe, effective and affordable antimalarial drugs. The displayed high in vivo antiplasmodial activity and lack of toxic effect render $M$. senegalensis a candidate for the bioassay-guided isolation of compounds which could develop into new lead structures and candidates for drug development programmes against human malaria.

\section{Competing interests}

The authors declare that they have no competing interests.

\section{Authors' contributions}

HMM, AYK and PPM conceived the study and were involved in all stages of the investigation. WW and SJK were involved in the in vivo animal experimentation; SFR and KPS carried out statistical data analysis. NAK, VAN, CPI, JWO, RS and BM carried out processing, extraction and preparation of extracts for the study. JJM and MNM coordinated the study. All authors contributed to the data interpretation and writing of the manuscript. All authors have read and approved the manuscript.

\section{Acknowledgements}

This work was supported by the Special Programme for Research and Training in Tropical Diseases (TDR) grant (A10504). Kagera Region government is thanked for permitting the collection of studied plant in the region. Mr. Hashim Kamugunda and Mr. Ignas Kashana are specially thanked for their immense support during the survey and for their help in the collection and field processing of the studied medicinal plant.

\section{Author details}

'Department of Traditional Medicine Research, National Institute for Medical Research, 3 Barack Obama Drive, P.O. Box 9653, 11101 Dar es Salaam, Tanzania. ${ }^{2}$ Ngongongare Medical Research Centre, P.O Box 514, Usa River, Arusha, Tanzania. ${ }^{3}$ Traditional Medicine Unit, Ministry of Health and Social Welfare, P.O. Box 9083, Dar es Salaam, Tanzania. ${ }^{4}$ Headquarters, National Institute for Medical Research, 3 Barack Obama Drive, P.O. Box 9653, 11101 Dar es Salaam, Tanzania. ${ }^{5}$ Government Chemist Laboratory Agency, P. O. Box 164, Dar es Salaam, Tanzania.

Received: 12 April 2014 Accepted: 20 December 2014

Published online: 14 February 2015

\section{References}

1. Jansen PCM, Mendes O. Plantas medicinais - seu uso tradicional em Mocambique. Maputo: Imprensa do Partido; 1991.

2. Gessler MC, Tanner M, Chollet J, Nkunya MHH, Heinrich M. Tanzanian medicinal plants used traditionally for the treatment of malaria: In vivo antimalarial and in vitro cytotoxic activities. Phytother Res. 1995;9:504-8.

3. Sanogo R. Medicinal plants traditionally used in Mali for dysmenorrhea. Afr J Tradit Complement Altern Med. 2011;8(5 Suppl):90-6.

4. Kihwelo PF. Traditional intellectual property protection in Tanzania: the case of traditional medicinal knowledge. PhD Thesis. Dar es Salaam, Tanzania: Open University of Tanzania; 2009. http://repository.out.ac.tz/103/.

5. Atindehou KK, Schmid C, Brun R, Koné MW, Traore D. Anti-trypanosomal and anti-plasmodial activity of medicinal plants from Côte d'Ivoire. J Ethnopharmacol. 2004;90:221-7

6. Hussein G, Nakamura N, Meselhy MR, Masao Hattori M. Phenolics from Maytenus senegalensis. Phytochemistry. 1999;50:689-94.

7. Hutchings A, Scott A, Lewis G, Cunningham A. Zulu medicinal plants - an inventory. Pinetown: University of Natal Press; 1996.

8. Mueller M, Mechler E. Medicinal plants in tropical countries: traditional useexperience-facts. Stuttgart: Thieme. 2005.

9. El Tahir A, Satti GMH, Sami A, Khalid SA. Antiplasmodial activity of selected Sudanese medicinal plants with emphasis on Maytenus senegalensis (Lam.) Exell. J Ethnopharmacol. 1999;64:227-33.

10. Muregi FW, Ishih A, Suzuki T, Kino H, Amano T, Mkoji GM, et al. In vivo antimalarial activity of aqueous extracts from Kenyan medicinal plants and their chloroquine (CQ) potentiation effects against a blood-induced CQresistant rodent Parasite in mice. Phytother Res. 2007;21:337-43.

11. Gessler MC, Nkunya MH, Mwasumbi LB, Heinrich M, Tanner M. Screening Tanzanian medicinal plants for antimalarial activity. Acta Trop. 1994;56:65-77.

12. WHO. National policy on traditional medicine and regulation of herbal medicines. Report of WHO global survey. Geneva: World Health Organization; 2005.

13. Kitua AY, Malebo HM. Malaria control in Africa and the role of traditional medicine. In: Willcox M, Rasoanaivo P, Bodeker G, editors. Traditional herbal medicines for modern times: traditional medicinal plants and malaria. Washington, D.C: CRC Press LLC; 2004. p. 3-18. Part 1.

14. Kiringe JW. Ecological and anthropological threats to ethno-medicinal plant resources and their utilization in Maasai communal ranches in the Amboseli Region of Kenya. Ethnobotany Res Appl. 2005;3:231-41.

15. Klemick H, Leonard KL, Masatu MC. Defining access to health care: evidence on the importance of quality and distance in rural Tanzania. Am J Agric Econ. 2009:91:347-58.

16. Simba D, Kakoko D. Access to subsidized artemether-lumefantrine from the private sector among febrile children in rural setting in Kilosa, Tanzania. Tanzan J Health Res. 2012;14:1-8.

17. Peters W, Portus JH, Robinson BL. The chemotherapy of rodent malaria XXII. The value of drug resistant strains of $P$. berghei in screening for blood schizonticidal activity. Ann Trop Med Parasitol. 1975;69:155-71.

18. Peters W, Fleck SL, Robinson BL, Stewart LB, Jefford CW. The chemotherapy of rodent malaria. LX. The importance of formulation in evaluating the 
blood schizontocidal activity of some endoperoxide antimalarials. Ann Trop Med Parasitol. 2002;96:559-73.

19. WHO. Research Guidelines for Evaluating the Safety and Efficacy of Herbal Medicines, Manila, 1993.

20. Malebo HM, Tanja W, Cal M, Swaleh SM, Omolo MO, Hassanali A, et al. Antiplasmodial, anti-trypanosomal, anti-leishmanial and cytotoxicity activity of selected Tanzanian medicinal plants. Tanzan J Health Res. 2009;11:226-34.

21. Ahmed AS, McGaw LJ, Eloff JN. Evaluation of pharmacological activities, cytotoxicity and phenolic composition of four Maytenus species used in southern African traditional medicine to treat intestinal infections and diarrhoeal diseases. BMC Complement Altern Med. 2013;13:100.

22. Sanogo R, Maiga A, Diallo D. Activités analgesique et anti-inflammatoire des extraits de Maytenus senegalensis, Stereospermum kuntrianum et Trichilia emetica utilisés dans le traitement traditionnel des dysmenorrhées au Mali. Pharm Med Trad Afr. 2006;14:123-36.

23. Sosa S, Morelli CF, Tubaro A, Cairoli P, Speranza G, Manitto P. Anti-inflammatory activity of Maytenus senegalensis root extracts and of maytenoic acid. Phytomedicine. 2007;14:109-14.

24. da Silva G, Taniça M, Rocha J, Serrano R, Gomes ET, Sepodes B, et al. In vivo anti-inflammatory effect and toxicological screening of Maytenus heterophylla and Maytenus senegalensis extracts. Hum Exp Toxicol. 2010;30:693-700.

25. Haule EE, Moshi MJ, Nondo RSO, Mwangomo DT, Mahunnah RLA. A study of antimicrobial activity, acute toxicity and cytoprotective effect of a polyherbal extract in a rat ethanol-HCl gastric ulcer model. BMC Res Notes. 2012;5:546.

\section{Submit your next manuscript to BioMed Central and take full advantage of:}

- Convenient online submission

- Thorough peer review

- No space constraints or color figure charges

- Immediate publication on acceptance

- Inclusion in PubMed, CAS, Scopus and Google Scholar

- Research which is freely available for redistribution 